\title{
Influence of adrenergic receptors on ovarian progesterone secretion in the pseudopregnant cat and oestradiol secretion in the oestrous cat
}

\author{
A. G. Wheeler, M. Walker and J. Lean* \\ Department of Physiology and Pharmacology, University of Queensland, St Lucia, \\ Queensland 4067, Australia
}

\begin{abstract}
Summary. The infusion of isoprenaline or propranolol into the abdominal aorta of the pseudopregnant cat caused an increase or decrease respectively in the ovarian progesterone secretion rate. These observations suggest that the sympathetic innervation of the ovary has a physiological influence on normal progesterone secretion, and this mechanism may explain stress-related increases in progesterone concentrations. The infusion of isoprenaline or propranolol after the stimulation of follicular growth had no consistent or convincing effect on oestradiol secretion.
\end{abstract}

\section{Introduction}

There is a substantial extrinsic innervation of the mammalian ovary (Neilson et al., 1970) associated with blood vessels, forming plexuses around primary follicles, entering the membrana granulosa of maturing and mature follicles, and associated with the smooth muscle cells in the theca externa of mature follicles (Fink \& Schofield, 1971); these nerves are predominantly adrenergic, with some cholinergic. It has been demonstrated that stimulating or inhibiting $\beta$-adrenergic neurotransmitter receptors affects progesterone steroidogenesis in terms of ovarian tissue content or secretion in vitro (cow: Condon \& Black, 1976; sheep: Jordan et al., 1978; rat: Ratner et al., 1980) and peripheral blood concentrations (human: Fylling, 1971; sheep: Flint et al., 1974). However, some experiments measuring blood progesterone concentrations in pregnant women (Carlström et al., 1978; Hanssens et al., 1983) and luteal tissue secretion in vitro (Richardson \& Mason, 1980) have yielded contradictory results. The only information on such influences on ovarian progesterone secretion rates, which might better indicate possible physiological roles for the ovarian innervation, was obtained in the rat (Zsolnai et al., 1982), in which the ovary is not particularly densely innervated (Burden \& Lawrence, 1980).

It has been suggested that the ovarian innervation is involved in the growth and maturation of follicles (Fink \& Schofield, 1971), and is responsible for the compensatory hypertrophy after unilateral ovariectomy (Burden \& Lawrence, 1977) and the unequal ovulatory activity of the left and right ovaries (Wheeler, 1978). We therefore examined the influence of the $\beta$-adrenergic receptors on oestrogen secretion rates (as an indicator of follicular activity) in animals with preovulatory follicles.

We chose the cat as the experimental animal because the comparatively dense innervation of its ovaries (Burden \& Lawrence, 1980) suggested a complementary abundance of neurotransmitter receptors that we could influence, and its size makes it suitable for acute experiments of this type. Although ovulation in the cat is induced by copulation (Longley, 1910), the mechanical stimulation of the vagina and the vaginal afferent nerves results in an increased $\mathrm{LH}$ concentration that induces

*Present address: Queensland Institute for Medical Research, Herston, Queensland 4006, Australia. 
ovulation (Glover et al., 1985), as in spontaneous ovulators; the ovarian innervation plays no apparent role in ovulation in induced ovulators (Lambertsen et al., 1976). The results of stimulating and blocking ovarian adrenergic receptors in the cat should therefore be generally applicable to other species, both induced and spontaneous ovulators.

The adrenergic receptor agonistic and antagonistic drugs that we intended to investigate could be expected to alter the performance of the cardiovascular system (e.g. heart rate, stroke volume, venous tone, vasoconstriction/dilatation); we therefore monitored arterial blood pressure and heart rate to identify and assess any such changes. The drugs were infused into the aorta cranially to the origins of the ovarian arteries to maximize the ovarian arterial blood concentrations of the drugs relative to the lower peripheral concentrations. Timed aliquants of the continuous flow of ovarian venous blood were collected so that the secretion rate for the period represented by each aliquant could be calculated, the secretion rate being the most sensitive indicator of any variation in ovarian secretion. These requirements suggested an acute experiment on an anaesthetized animal with euthanasia without recovery at the completion of the experiment.

\section{Materials and Methods}

Experimental procedure. Intact anoestrous cats were treated i.m. with 50 i.u. PMSG daily for 3 days (Folligon: Intervet International, Boxmeer, The Netherlands) to stimulate ovarian follicular development and on the following day 100 i.u. hCG (Chorulon: Intervet) was given i.m. to stimulate ovulation. Between 1 and 3 weeks later the animals were collected before feeding and anaesthetized with ketamine hydrochloride ( $70 \mathrm{mg}$ i.m.; Ketalar: Parke-Davis, Caringbah, N.S.W.) and later pentobarbitone sodium (6 mg i.v.; Sagatal: May \& Baker, West Footscray, Victoria). Further doses of anaesthetic were administered as required; this typically consisted of a further $20 \mathrm{mg}$ ketamine hydrochloride and $6 \mathrm{mg}$ pentobarbitone sodium after $1-2 \mathrm{~h}$. The animals were weighed (Tables $1-3)$.

A saphenous vein and the two femoral arteries were cannulated (polyethylene; $0.86 \mathrm{~mm}$ internal diameter, $1.27 \mathrm{~mm}$ external diameter; Dural Plastics, Dural, N.S.W.). The intra-venous cannula was short and used for the administration of pentobarbitone sodium and anticoagulant. The end of one intra-arterial cannula was positioned in the thoracic aorta; this cannula was connected to a transducer for the continuous recording of arterial blood pressure. The end of second intra-arterial cannula was positioned in the upper-abdominal aorta so as to be cranial to the origin of the ovarian arteries; this cannula was used for the infusion of isotonic saline and the experimental drugs. A corrugated rubber tube fastened around the upper abdomen and connected to a transducer allowed the recording of respiratory movements.

The abdomen was opened through the mid-line central incision and, with as little handling as possible, the two ovaries were inspected. When corpora lutea were present on both ovaries one was selected at random; on that side the uterine branches of the ovarian vein (del Campo \& Ginther, 1974) were ligated. Anticoagulant (2500 i.u. heparin i.v.; Sigma, St Louis, MO, U.S.A.) was administered and the ovarian vein (now carrying only ovarian venous blood) was cannulated near its origin from the posterior vena cava (right) or renal vein (left) in the short distance that this vein is separate from its complementary ovarian artery. To minimize any kinking of the vein, the cannula was led under the descending colon and out of the abdomen through a stab wound in the body wall on the other side; the cannula was then trimmed to minimize its length. The abdominal wound was repaired to minimize the trauma and heat loss.

The ovarian venous outflow was collected continuously into calibrated $10 \times 75 \mathrm{~mm}$ glass tubes; at 1 or $2 \mathrm{ml}$ intervals the time was noted and the collection tube changed. This allowed the ovarian blood flow to be calculated for each collection tube. Every fourth or fifth tube a sample of the blood was taken for packed cell volume (PCV) determination. The blood was centrifuged and the plasma stored at $-20^{\circ} \mathrm{C}$.

Saline $(9 \mathrm{~g} \mathrm{NaCl} / \mathrm{l})$ or the experimental drug was infused through the intra-arterial cannula ('Perfusor VI' adapted to use $1 \mathrm{ml}$ syringes; B. Braun Melsungen AG, Melsungen, West Germany) at about $1 \mathrm{ml}$ per $17 \mathrm{~min}$.

At the completion of each experiment the animal was killed with pentobarbitone sodium and the volumes of the infusion and collection cannulae were noted.

Progesterone secretion rates. The antiserum (11 P27; Fantl \& Wang, 1984) had cross-reactions of $100 \%$ with progesterone, $96 \%$ with $11 \alpha$-hydroxyprogesterone, $11 \%$ with $5 \alpha$-pregnane-3,20-dione, $4 \%$ with $6 \beta$-hydroxyprogesterone, $1 \%$ with pregnenolone, and $<1 \%$ with $20 \beta$-dihydroprogesterone, 17-hydroxyprogesterone and androstenedione; no other steroid cross-reacted at $>0 \cdot 1 \%$. The progesterone radioimmunoassay method has been described elsewhere (Wheeler \& Blackshaw, 1986). The efficiency of extraction was $80 \cdot 6 \pm 2 \cdot 28 \%(n=38)$. The repeated assay of ovarian venous plasma from a pseudopregnant cat gave a mean value of $219 \cdot 2 \pm 4 \cdot 87 \mathrm{ng} / \mathrm{ml}(n=20)$. The repeated assay of aliquants of plasma from an ovariectomized cat to which known amounts of progesterone had been added to give samples containing $0,1 \cdot 25,2 \cdot 5,5$ and $10 \mathrm{ng} / \mathrm{ml}$ gave data from which a regression line of $y=0 \cdot 381+1 \cdot 116 x$ (where $y$ is the assayed progesterone concentration and $x$ the added concentration, both in $\mathrm{ng} / \mathrm{ml}$ ) and a standard deviation of the regression coefficient of $0.049\left(t_{(112)}=23.0 ; P<0.001\right)$ were calculated (Snedecor \& Cochran, 1967). The intra- and inter-assay coefficients of variation (Dighe \& Hunter, 1974) were $9 \cdot 12$ and $12 \cdot 50 \%$ respectively. 
Table 1. Progesterone secretion rates (ng/min) before, during and after the infusion of isoprenaline, and the maximum secretion rate and its time of occurrence

\begin{tabular}{|c|c|c|c|c|c|c|c|}
\hline \multirow[b]{2}{*}{ Cat no. } & \multirow[b]{2}{*}{$\begin{array}{c}\text { Body } \\
\text { wt (kg) }\end{array}$} & \multirow{2}{*}{$\begin{array}{c}\text { Isoprenaline } \\
\text { infusion rate } \\
(\mu \mathrm{g} / \mathrm{min})\end{array}$} & \multirow[b]{2}{*}{ Pre-infusion } & \multirow[b]{2}{*}{ Infusion } & \multicolumn{2}{|c|}{ Peak secretion } & \multirow[b]{2}{*}{$\begin{array}{l}\text { Post- } \\
\text { infusion }\end{array}$} \\
\hline & & & & & $\begin{array}{c}\text { Rate } \\
\text { (ng/min) }\end{array}$ & $\underset{(\min )^{*}}{\text { Time }}$ & \\
\hline 38 & $3 \cdot 2$ & $2 \cdot 9$ & $160 \pm 13 \cdot 0(12)$ & $236 \pm 18.8(8)$ & 296 & 8.9 & $160 \pm 10 \cdot 9(10)$ \\
\hline 39 & $2 \cdot 5$ & 11.8 & $196 \pm 24 \cdot 6(9)$ & $216 \pm 10 \cdot 5(2)$ & \multicolumn{2}{|c|}{$-\dagger$} & $192 \pm 17 \cdot 5(5)$ \\
\hline 46 & 1.7 & $2 \cdot 8$ & $920 \pm 85.6(9)$ & $1523 \pm 71.0(2)$ & 1594 & 15.0 & $508 \pm 148 \cdot 0(3)$ \\
\hline 49 & 2.8 & $3 \cdot 2$ & $588 \pm 40 \cdot 9(16)$ & $791 \pm 65.2(5)$ & 2025 & $4 \cdot 2$ & $518 \pm 26 \cdot 2(8)$ \\
\hline 55 & $3 \cdot 4$ & $2 \cdot 9$ & $4170 \pm 430 \cdot 1(12)$ & $1989 \pm 136 \cdot 6(5)$ & \multicolumn{2}{|c|}{$-\ddagger$} & $2246 \pm 216 \cdot 5(18)$ \\
\hline $58 \mathrm{~b}$ & $3 \cdot 3$ & $2 \cdot 9$ & $932 \pm 23 \cdot 5(5)$ & $1093 \pm 147.6(4)$ & 1508 & 1.5 & $1075 \pm 87.1(10)$ \\
\hline $73 a$ & - & $2 \cdot 9$ & $1393 \pm 251 \cdot 4(19)$ & $387 \pm 36 \cdot 2(6)$ & \multicolumn{2}{|c|}{$-\ddagger$} & $1732 \pm 249.8(26)$ \\
\hline $73 b$ & - & $2 \cdot 9$ & $1802 \pm 240.7(26)$ & $2387 \pm 272 \cdot 6(6)$ & 3268 & 1.5 & $1759 \pm 233.2(13)$ \\
\hline 84 & $3 \cdot 0$ & $5 \cdot 6$ & $660 \pm 54 \cdot 5(10)$ & $917 \pm 260 \cdot 3(4)$ & 1405 & $12 \cdot 8$ & $1103 \pm 331.6(6)$ \\
\hline 127 & $2 \cdot 9$ & 6.6 & $707 \pm 70.5(12)$ & $1137 \pm 378.6(5)$ & 2438 & $15 \cdot 6$ & $751 \pm 128 \cdot 5(13)$ \\
\hline
\end{tabular}

Values are mean \pm s.e.m. for the no. of samples in parentheses.

*From start of infusion.

$\nmid$ No significant variation in the progesterone secretion rate.

\$Progesterone secretion rate decreased during the infusion period.

Table 2. Progesterone secretion rates (ng/min) before, during and after the infusion of propranolol, and the time taken for the secretion rate to decrease to less than $50 \%$ of the pre-infusion mean

\begin{tabular}{|c|c|c|c|c|c|c|}
\hline Cat no. & $\begin{array}{c}\text { Body } \\
\text { wt (kg) }\end{array}$ & $\begin{array}{c}\text { Propranolol } \\
\text { infusion rate } \\
\text { ( } \mu \mathrm{g} / \mathrm{min})\end{array}$ & Pre-infusion & Infusion & $\begin{array}{l}\text { Time for } \\
\text { decrease } \\
\text { to }<50 \% \text { of } \\
\text { pre-infusion } \\
\text { rate }^{*} \text { (min) }\end{array}$ & Post-infusion \\
\hline 36 & $2 \cdot 4$ & $1 \cdot 2$ & $1355 \pm 65.6(9)$ & $915 \pm 107 \cdot 5(3)$ & $18 \cdot 3$ & $366 \pm 33.9(5)$ \\
\hline 53 & $2 \cdot 8$ & $1 \cdot 2$ & $2238 \pm 219 \cdot 2(13)$ & $1376 \pm 53 \cdot 1(4)$ & $20 \cdot 1$ & $266 \pm 193 \cdot 3(5)$ \\
\hline $58 \mathrm{a}$ & $3 \cdot 3$ & $1 \cdot 2$ & $1435 \pm 76.9(11)$ & $1079 \pm 93.8(8)$ & 11.7 & $932 \pm 23.5(5)$ \\
\hline 60 & $2 \cdot 9$ & $1 \cdot 2$ & $325 \pm 77.9(16)$ & $560 \pm 32 \cdot 8(18)$ & $-\dagger$ & $407 \pm 68 \cdot 6(21)$ \\
\hline 109b & $2 \cdot 2$ & $3 \cdot 0$ & $5627 \pm 462 \cdot 6(13)$ & $2373 \pm 972.9(6)$ & $4 \cdot 2$ & $268 \pm 69 \cdot 5(2)$ \\
\hline 126 & $3 \cdot 2$ & $2 \cdot 8$ & $3745 \pm 157.5(12)$ & $2226 \pm 173.6(8)$ & $7 \cdot 3$ & $1748 \pm 114 \cdot 2(10)$ \\
\hline
\end{tabular}

Values are mean \pm s.e.m. for the no. of samples in parentheses.

*From start of infusion.

†Progesterone secretion rate increased.

Table 3. Follicular oestradiol secretion rates $(\mathrm{pg} / \mathrm{min})$ before, during and after the infusion of isoprenaline or propranolol

\begin{tabular}{|c|c|c|c|c|c|c|}
\hline Cat no. & $\begin{array}{c}\text { Body } \\
\text { wt }(\mathrm{kg})\end{array}$ & $\begin{array}{l}\text { Infusion } \\
\text { rate } \\
(\mu \mathrm{g} / \mathrm{min})\end{array}$ & Pre-infusion & Infusion & Post-infusion & $\begin{array}{l}\text { Analysis of } \\
\text { variance }\end{array}$ \\
\hline \multicolumn{7}{|c|}{ Isoprenaline } \\
\hline 88 & $2 \cdot 0$ & 6 & $234 \pm 8 \cdot 0(9)$ & $214 \pm 2 \cdot 3(3)$ & $228 \pm 13.4(9)$ & $F_{(2,18)}=0.45 ; P>0.05$ \\
\hline 94 & $2 \cdot 6$ & 12 & $328 \pm 20.9(15)$ & $451 \pm 30.9(9)$ & $345 \pm 20 \cdot 2(8)$ & $F_{(2.29)}=7.21 ; P<0.01$ \\
\hline \multicolumn{7}{|c|}{ Propranolol } \\
\hline 97 & $2 \cdot 5$ & $3 \cdot 4$ & $2511 \pm 124 \cdot 2(13)$ & $3186 \pm 149 \cdot 3(6)$ & $2366 \pm 131 \cdot 9(10)$ & $F_{(2,26)}=7.58 ; P<0.01$ \\
\hline
\end{tabular}

Values are mean \pm s.e.m. for the no. of samples in parentheses. 
The plasma progesterone concentrations were corrected using the PCVs and blood flows to obtain the ovarian progesterone secretion rates (the arterial blood concentrations of progesterone. were disregarded as negligible), each secretion rate being the mean for the period over which that volume of blood was collected. This procedure reduced the variation in the progesterone secretion rates.

Follicular oestradiol secretion rates. On the day on which the animals would otherwise have had their PMSGstimulated follicles ovulated with hCG, isoprenaline or propranolol were infused to identify their effects on the ovarian follicular of oestradiol.

The oestradiol immunoassay was conducted as described for progesterone (Wheeler \& Blackshaw, 1986) with the following differences: $200 \mu \mathrm{l}$ aliquants of plasma were extracted with $2 \mathrm{ml}$ diethyl ether, the standards ranged from 1 to $1000 \mathrm{pg} /$ tube (oestradiol-17 $\beta$; Sigma) and the radioactive label was $\left[2,4,6,7-{ }^{3} \mathrm{H}\right]$ oestradiol (Amersham International, Sydney, N.S.W.; 3.37 TBq/mmol). The antiserum used (6EI), described by Fantl \& Wang (1984), bount to oestradiol $(100 \%), 6 \alpha$-hydroxyoestradiol $(45 \%), 16$-oxo-oestradiol $(5 \%)$, oestrone $(0.04 \%)$ and oestriol $(1 \%)$; no other steroid investigated bound at $>0.01 \%$. The final dilution of the antiserum was 1 in 90000 .

The oestradiol secretion rates were calculated from the plasma concentrations, PCVs, times and volumes as described for the progesterone secretion rates.

Statistical analyses. Using the measured cannula volumes and flow rates, both the infusion and secretion times were corrected to the times that infused drugs arrived at the ovary and the ovary secreted the steroid so as to be comparable. This correction did not take into account the unknown volumes of the aorta and ovarian artery, and the ovarian vein; although these errors would invalidate any consideration of precise time relationships they were considered to be small (of the order of 1-2 min) and not prejudicial for the present purposes.

The significances of any differences between and pre-infusion, infusion and post-infusion periods were examined using analysis of variance (Sokal \& Rohlf, 1981).

\section{Results}

The total volume of blood collected during these experiments varied from 22.9 to $84.4 \mathrm{ml}$ (mean \pm s.e.m: $54.4 \pm 4.02 \mathrm{ml} ; n=19)$. These volumes represented $16.4-44.4 \%(28.8 \pm 1.89 \% ; n=17)$ of the estimated total blood volumes $(66.7 \mathrm{ml}$ blood per kg body weight; Spink et al., 1966). The PCV at the beginning of the experiments was between 21 and $47 \cdot 5 \%(34 \cdot 1 \pm 1 \cdot 72 \% ; n=19)$ and decreased by the end to between 14 and $38 \%(25 \cdot 6 \pm 1 \cdot 65 \% ; n=19)$.

The pre-drug infusion mean progesterone secretion rates for pseudopregnant cats varied between animals from a minimum of $160 \pm 13.0 \mathrm{ng} / \mathrm{min}$ in Cat 38 to a maximum of $5626 \pm 462.6 \mathrm{ng} / \mathrm{min}$ in Cat 109 ; the median was $1078 \pm 75 \cdot 1 \mathrm{ng} / \mathrm{min}(n=26)$.

The pre-infusion progesterone secretion rates were unrelated to the numbers of corpora lutea present in the ovary on the side cannulated $\left(r_{(13)}=0.234 ; P>0.05\right)$.

The effect of a continuous saline infusion with continuous ovarian venous blood collection on the ovarian progesterone secretion rate, blood flow, heart rate and arterial blood pressures are shown in Fig. 1. Except for the omission of a drug the protocol was the same as that followed in the other experiments. There was no significant variation in the progesterone secretion rates during three arbitrarily chosen periods corresponding to the pre-infusion, infusion and post-infusion periods $\left(F_{(2,19)}=0.82 ; P>0.05\right)$.

Within 1.5 to $18.8 \mathrm{~min}$ of the start. of the infusions of isoprenaline in 7 cats (Table 1 ) the progesterone secretion rates increased $(P<0.05)$ to a maximum rate betwen 162 and $398 \%$ of the preinfusion mean rates; a typical response is shown in Fig. 2. After the peak in all instances the progesterone secretion rate decreased to a rate similar to that measured during the pre-infusion periods. The post-infusion mean for Cat 84 is considerably higher than the pre-infusion mean because the peak secretion rate after the start of the infusion was not reached until the first sample of the post-infusion period in this experiment. One additional infusion (Cat 39) had no apparent effect on the progesterone secretion rate, and two other infusions (Cats 55 and 73a) were associated with lesser progesterone secretion rates.

All the isoprenaline infusions resulted in a lower ovarian blood flow, the mean for the 10 experiments decreasing from a pre-infusion value of $0.898 \pm 0.141 \mathrm{ml} / \mathrm{min}$ to $0.557 \pm 0.075 \mathrm{ml} / \mathrm{min}$, and remained low at $0.582 \pm 0.099 \mathrm{ml} / \mathrm{min}$ during the post-infusion period. Isoprenaline had a small, 


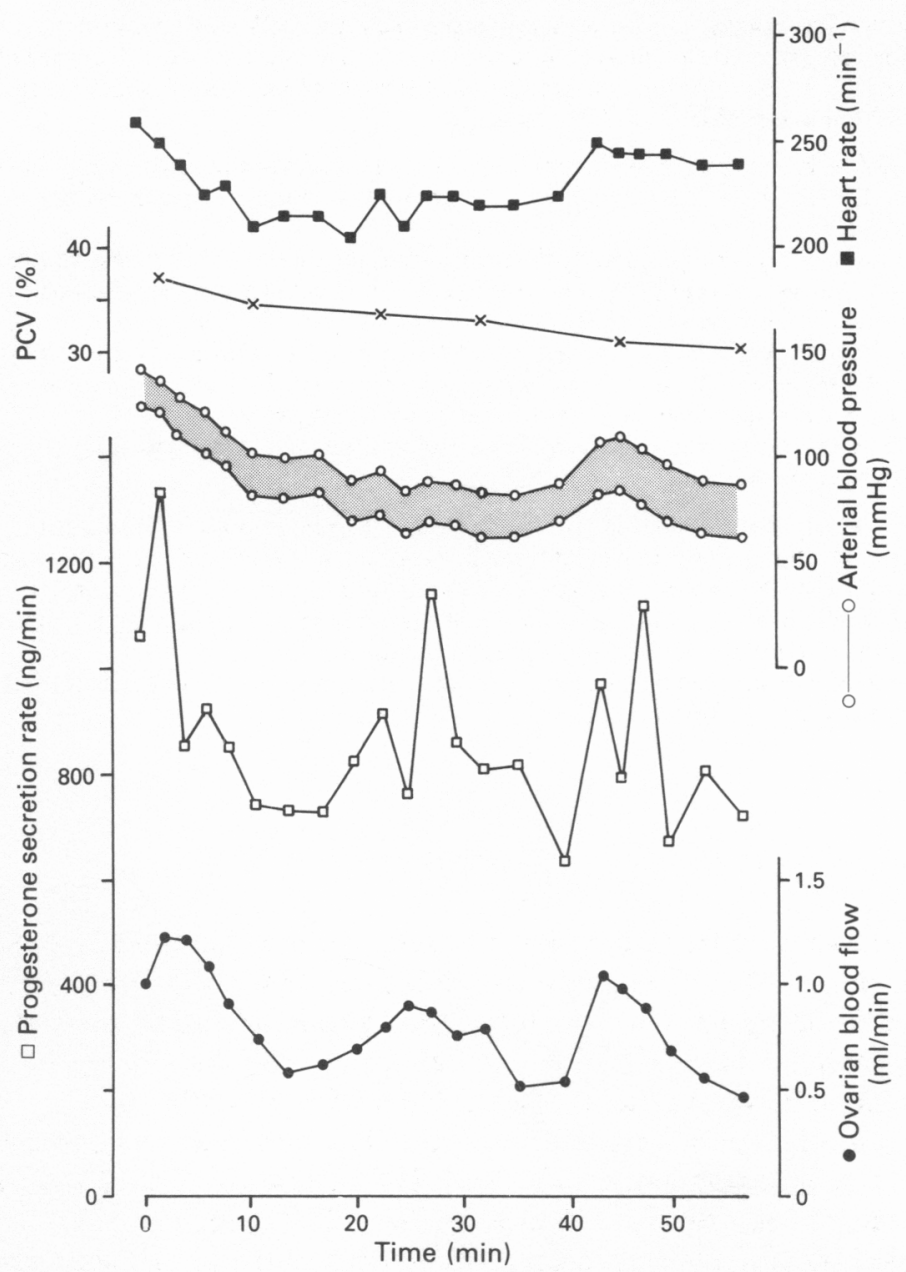

Fig. 1. Ovarian progesterone secretion rate $(\square-\square)$ and blood flow ( $\square-0$ ), heart rate $(\mathbf{D}), \operatorname{PCV}(\times-\times)$ and systolic and diastolic arterial blood pressures $(0-0)$ during continuous saline infusion in the pseudopregnant cat (Cat 42).

variable effect on the heart rate (from 97 to $127 \%$ of the pre-infusion rates) and consistently decreased arterial systolic (to $76.9 \%$ ) and diastolic (to $64.7 \%$ ) blood pressures. There was no consistent effect on the respiratory rates.

Of the 6 propranolol infusions (Table 2), 5 produced a marked decrease in the progesterone secretion rates, to $<50 \%$ of the pre-infusion mean with $4 \cdot 2-20 \cdot 1 \mathrm{~min}$ of the start of the infusion. This low secretion rate was sustained in each case for the remainder of the experiment. The results for Cat 109 are shown in Fig. 3. One infusion, Cat 60 (an animal in which the progesterone secretion rate was already low), caused an increased secretion rate.

In response to propranolol the ovarian blood flow similarly declined, except in Cat 60 in which the blood flow increased. With this exception the pre-infusion mean for the 5 experiments was $1.207 \pm 0.227 \mathrm{ml} / \mathrm{min}$, the infusion being associated with a decrease to $0.778 \pm 0.151 \mathrm{ml} / \mathrm{min}$ 


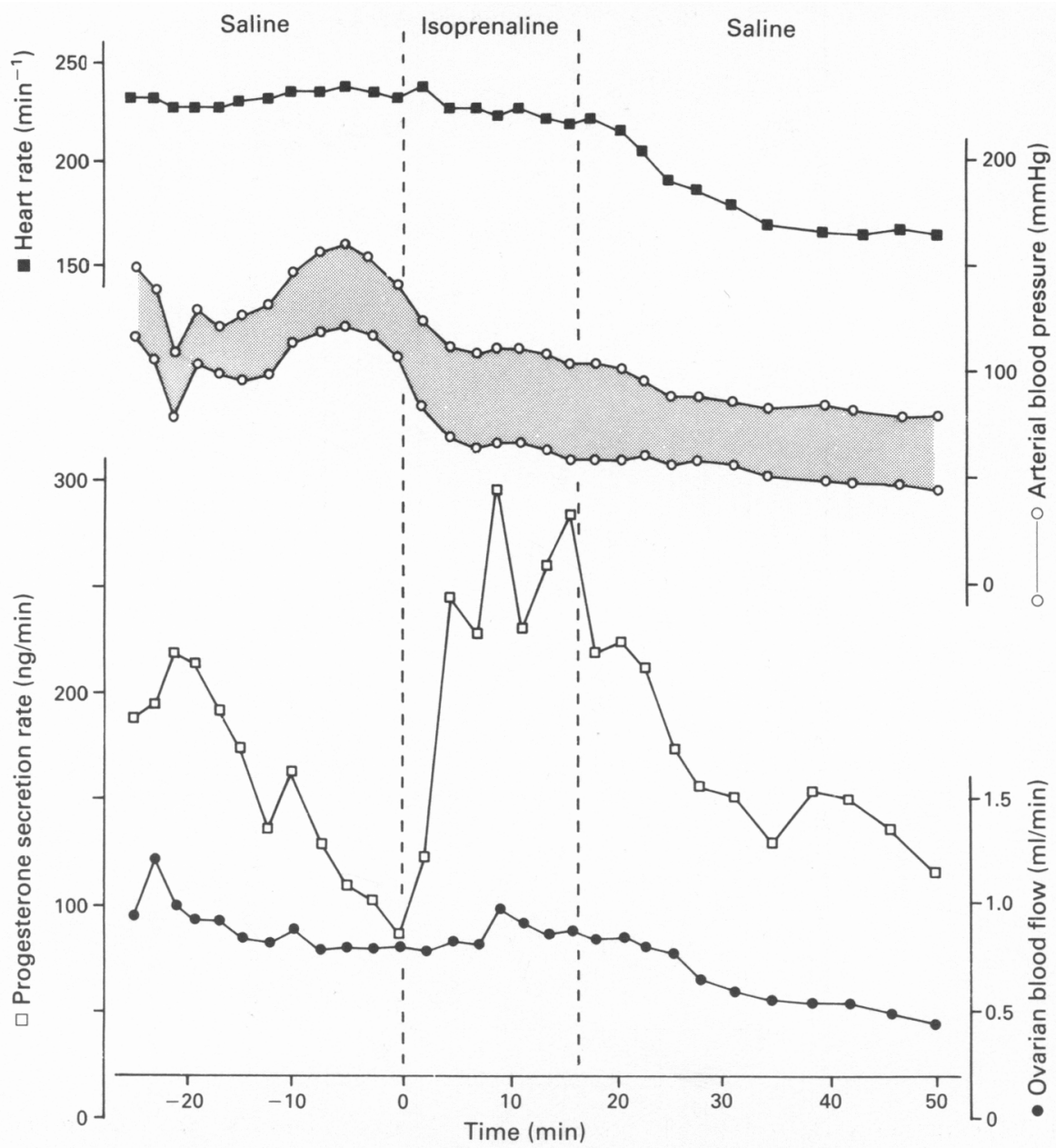

Fig. 2. Ovarian progesterone secretion rate $(\square-\square)$ and blood flow ( $\square-\bullet$ ), heart rate $(\boldsymbol{\square}-\mathbf{a}$ ) and systolic and diastolic arterial blood pressures $(\mathrm{O}-\mathrm{O})$ before, during and after the infusion of isoprenaline (Cat 38).

with a further decrease to $0.387 \pm 0.115 \mathrm{ml} / \mathrm{min}$ during the post-infusion period. There were no significant or consistent effects on the heart rate, arterial blood pressures or respiratory rate.

The oestradiol secretion rate was measured in one animal during the induced luteal phase and the mean for the pre-infusion period was $1 \cdot 12 \pm 0.042 \mathrm{pg} / \mathrm{min}(n=13$; Cat 38)

In the oestrous animals one of the two isoprenaline infusions (Cat 94), and the propranolol infusion (Cat 97), were associated with significant variations in the follicular oestradiol secretion rate (Table 3). The patterns of the variation in the oestradiol secretion rate for these two animals is shown in Fig. 4.

Two experiments were rejected due to the ovarian oestradiol secretion rates being particularly low: $18.1 \pm 0.59(n=7)$ and $8.1 \pm 1.03(n=10) \mathrm{pg} / \mathrm{min}$; these data were interpreted as indicating that the ovarian follicles were not as mature as had been expected. 


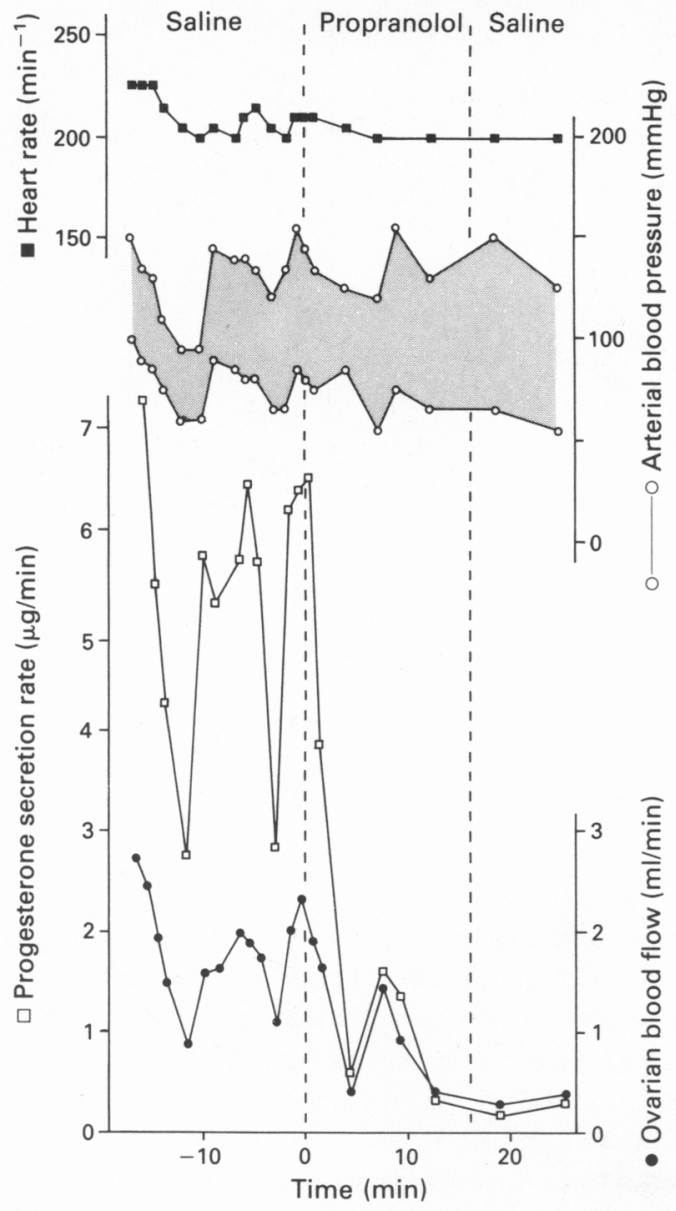

Fig. 3. Ovarian progesterone secretion rate $(\square-\square)$ and blood flow ( $\square-\bullet$ ), heart rate ( $-\square)$ and systolic and diastolic arterial blood pressures $(0-0)$ before, during and after the infusion of propranolol (Cat 109b).

\section{Discussion}

These results indicate that isoprenaline, a $\beta$-adrenergic agonist, enhanced ovarian luteal progesterone secretion rates, while propranolol, an adrenergic antagonist, has a depressive effect. Since propranolol has no direct action, and works rather by blocking the adrenergic receptor from stimulation by the endogenous neurotransmitter or administered agonists, the reduction in the progesterone secretion rate in response to propranolol described here suggests that the measured pre-infusion secretion rate was itself the consequence of endogenous, physiological adrenergic stimulation. This agrees with the earlier observation of decreased peripheral progesterone concentrations in sheep with denervated ovaries (Wheeler \& Blackshaw, 1986). Presumably therefore, variation in the activity of the autonomic sympathetic nervous system has an effect similar to that produced by the drugs used here, increasing sympathetic tone increasing adrenergic neurotransmitter (principally noradrenaline) and adrenal medulla hormone (principally adrenaline) release and consequently ovarian progesterone secretion.

These observations extend earlier findings that adrenergic stimulation increases progesterone concentrations produced by the human (Fylling, 1971) and sheep (Flint et al., 1974) placenta, 


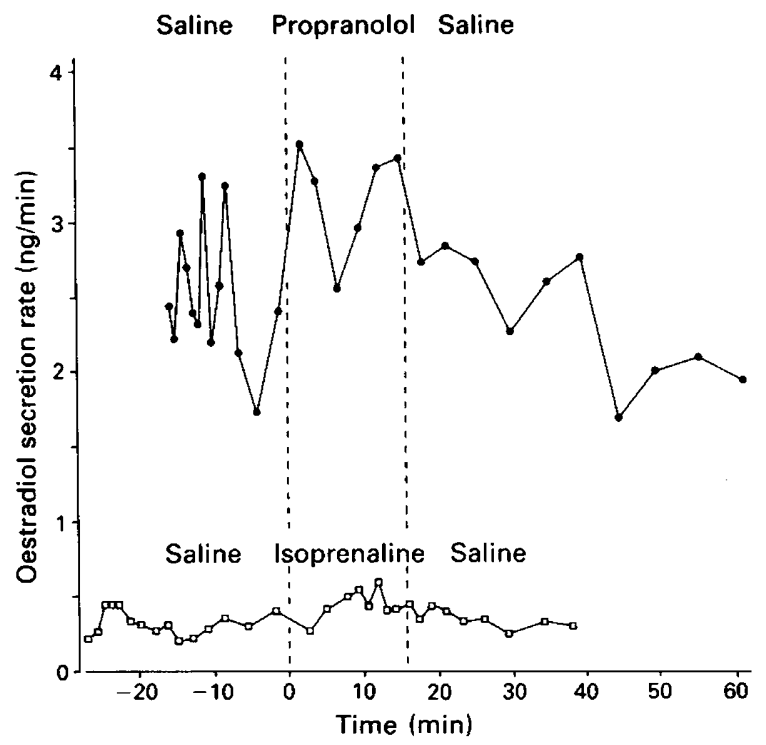

Fig. 4. Ovarian follicular oestradiol secretion rate before, during and after the infusion of propranolol (Cat 97; - - ) and isoprenaline (Cat 94; $\square-\square$ ).

secretion in vitro by bovine (Condon \& Black, 1976), ovine (Jordan et al., 1978) and rat (Ratner et al., 1980) luteal tissue and human placental tissue (Caritis et al., 1983), and rat ovarian secretion (Zsolnai et al., 1982). Most research on the effects of adrenergic neurotransmitters and sympathiometic drugs on progesterone secretion has been conducted on pregnant women or sheep, or luteal or placental tissue in vitro. Apart from that reported by Zsolnai et al. (1982) this seems to be the only study on luteal progesterone secretion. Further, apart from the similar finding by Godkin $e t$ al. (1977) who used bovine luteal tissue in vitro this is the only demonstration that a $\beta$-adrenergic antagonist (propranolol) can reduce the progesterone secretion rate.

There is evidence that stress, and presumably increased sympathetic tone (Selye, 1950), stimulates increased progesterone concentrations. Undernutrition of the sheep results in greater peripheral progesterone concentrations (Cumming et al., 1971). Similarly, extreme (stressful) ambient temperatures, both low (ewes: Lamond et al., 1972; cows: Rosenberg et al., 1982; buffalo cows: Rao \& Pandey, 1982) and high (cows: Stott \& Wiersma, 1973; ewes: Wheeler \& Blackshaw, 1986), have been associated with increased peripheral progesterone concentrations. Further evidence is provided by the decrease in the plasma progesterone concentration during a 3-h intravenous infusion of saline into early pregnant women (Fylling, 1971), presumably due to the subjects acclimatising to the unfamiliar procedure with a consequent decreasing sympathetic stimulation of steroid secretion.

There may be a relationship between changes in the sympathetic tone induced by the emotional anxiety and physiological stress in female prisoners of war and their observed secondary amenorrhea (Whitacre \& Barrera, 1944). Similarly, the stress of leaving the family home has been blamed for the regression to juvenile-type anovulation menstrual cycles in young ladies (Metcalf et al., 1983). These are just two of the many effects of stress on reproduction that are difficult to explain (Ramaley, 1981), but may be mediated by the autonomic innervation of the gonad.

The depression of endogenous progesterone secretion by $\beta$-antagonists (Godkin et al., 1977) has possibilities as a post-coital contraceptive administered either early in the luteal phase of the cycle to interfere with the transport of the fertilized ovum (Black \& Asdell, 1959), late in the luteal phase to induce luteal regression (McCracken, 1980; Okulicz et al., 1981). A post-coital contraceptive would fill a useful gap in the range of contraceptives currently available, all of which 
require a certain amount of premeditation and therefore do not cater for occasional and infrequent sexual contact.

The rapid and temporary nature of the isoprenaline-stimulated increases in the progesterone secretion rates presumably reflects the similar pattern found in the concentration of the mediator of this effect, cyclic adenosine monophosphate (Norjavaara et al., 1983) and the brief half-life of the drug (Weiner, 1980). The sustained depression caused by propranolol is presumably due to this drug's long half-life (4 h; Kornhauser et al., 1978).

In all the experiments using pseudopregnant cats except two (Cats 60 and 124) the ovarian blood flow during the infusion period was less than that during the preceding period. Since this decrease occurred irrespective of the drug infused, this change in the ovarian blood flow was presumably due to a general systemic vasoconstriction by the animal in response to the decreasing blood volume caused by the continuous collection of the ovarian venous blood.

Although one of the two isoprenaline infusions and the propranolol infusion appeared to have statistically significant effects on the follicular oestradiol secretion rate, the pattern of neither variation is convincing, and the $\beta$-adrenergic agonist (isoprenaline) and antagonist (propranolol) apparently similarly increased the oestradiol secretion rate. Therefore, although there appear to be no differences between follicular and luteal $\beta$-adrenergic receptor concentrations (Jordan, 1980), there was no convincing influence of the $\beta$-adrenergic receptors on ovarian follicular activity, agreeing with earlier findings for the rat (Adashi \& Hsueh, 1981) and disagreeing with a subsequent report (Zsolnai et al., 1982). Nevertheless, this observation is disappointing since the oestradiol secretion rate is generally presumed to reflect ovarian follicular growth and development, which in turn is a necessary pre-requisite for ovulation. These observations fail to support earlier evidence that the ovarian innervation influences follicular growth and maturation in hypophysectomized mice (Grob, 1974) and ovulation in hens (Ferrando \& Nalbandov, 1969), rabbit (Virutamasen et al., 1971) and rat (Peppler \& Jacobs, 1976; Kannisto et al., 1985), and that denervation results in increased oestradiol concentrations (Chihal et al., 1976). These conflicting findings regarding the influence of ovarian innervation on follicular oestradiol secretion, growth and maturation and ovulation leave unresolved proposals that such ovarian innervation may be the mechanism by which compensatory hypertrophy following unilateral ovariectomy (Burden \& Lawrence, 1977) and the inequality of ovulatory activity between the left and right ovaries (Wheeler, 1978) might be produced.

The variability of the progesterone secretion rates may have been due to transitory kinking of the blood vessels and cannula that we were unaware of, or a reflection of the pulsatile nature of progesterone secretion (Bäckström et al., 1982).

The low oestradiol secretion rates in 2 of the 5 animals were surprising since these cats had all been treated with PMSG in the same way as the other animals that subsequently received hCG and invariably ovulated and formed corpora lutea.

The progressive and sustained decrease in the arterial blood pressures observed during the salineonly infusion (Fig. 1) are presumably similarly due to the decreasing blood volume as the ovarian venous outflow was collected. This effect is therefore probably present in all the experiments.

We thank ICI Australia Operations for the gift of propranolol ('Inderal'); Sterling Pharmaceuticals for the gift of isoprenaline ('Isuprel'); Dr Vera Fantl for the gift of antisera to oestradiol and progesterone; and Barbara Beasley for invaluable technical assistance.

\section{References}

Adashi, E.Y. \& Hsueh, A.J.W. (1981) Stimulation of $\boldsymbol{\beta}_{2}$ adrenergic responsiveness by follicle-stimulating hormone in rat granulosa cells in vitro and in vivo. Endocrinology 108, 2170-2178.
Bäckström, C.T., McNeilly, A.S., Leask, R.M. \& Baird, D.T. (1982) Pulsatile secretion of LH, FSH, prolactin, oestradiol and progesterone during the human menstrual cycle. Clin. Endocr. 17, 29-42. 
Black, D.L. \& Asdell, S.A. (1959) Mechanism controlling entry of ova into rabbit uterus. Am. J. Physiol. 197, 1275-1278.

Burden, H.W. \& Lawrence, I.E., Jr (1977) The effect of denervation on compensatory ovarian hypertrophy. Neuroendocrinology 23, 368-378.

Burden, H.W. \& Lawrence, I.E., Jr (1980) Nerve supply of the ovary. In Biology of the Ovary, pp. 99-105. Eds P. M. Motta \& E. S. E. Hafez. Martinus Nijhoff, The Hague.

Caritis, S.N., Hirsch, R.P. \& Zeleznik, A.J. (1983) Adrenergic stimulation of placental progesterone production. J. clin. Endocr. Metab. 56, 969-972.

Carlström, K., Lunell, N.O., Persson, B. \& Wager, J. (1978) Actions of salbutamol in late pregnancy. Horm. Metab. Res. 10, 434-438.

Chihal, H.J.W., Weitsen, H.A., Stone, S.C. \& Peppler, R.D. (1976) Autonomic innervation and plasma estradiol-17 $\beta$ and progesterone levels in rats with subcutaneous ovarian autografts. Cell Tiss. Res. 175, $113-121$.

Condon, W.A. \& Black, D.L. (1976) Catecholamineinduced stimulation of progesterone by the bovine corpus luteum in vitro. Biol. Reprod. 15, 573-578.

Cumming, I.A., Mole, B.J., Obst, J., Blockey, M.A. de B., Winfield, C.G. \& Goding, J.R. (1971) Increase in plasma progesterone caused by undernutrition during early pregnancy in the ewe. $J$. Reprod. Fert. 24, 146-147.

Del Campo, C.H. \& Ginther, O.J. (1974) Arteries and veins of uterus and ovaries in dogs and cats. Am. J. Vet. Res. 35, 409415.

Dighe, K.K. \& Hunter, W.M. (1974) A solid-phase radioimmunoassay for plasma progesterone. Biochem. $J$. 143, 219-231.

Fantl, V.E. \& Wang, D.Y. (1984) Simultaneous production of monoclonal antibodies to dehydroepiandrosterone, oestradiol, progesterone and testosterone. $J$. Endocr. 100, 367-376.

Ferrando, G. \& Nalbandov, A.V. (1969) Direct effect on the ovary of the adrenergic blocking drug dibenzyline. Endocrinology 85, 38-42.

Fink, G. \& Schofield, G.C. (1971) Experimental studies on the innervation of the ovary in cats. J. Anat. 109, $115-126$.

Flint, A.P.F., Anderson, A.B.M. \& Turnbull, A.C. (1974) Control of utero-ovarian and peripheral venous plasma progesterone by $\beta$-sympathomimetic drugs in pregnant sheep. J. Endocr. 63, 253-254.

Fylling, P. (1971) Vasopressin-induced increase in peripheral plasma progesterone levels during early human pregnancy. Acta endocr. Copenh. 66, 273-282.

Glover, T.E., Watson, P.F. \& Bonney, R.C. (1985) Observations on variability in $\mathbf{L H}$ release and fertility during oestrus in the domestic cat (Felis catus). $J$. Reprod. Fert. 75, 145-152.

Godkin, J.D., Black, D.L. \& Duby, R.T. (1977) Stimulation of cyclic AMP and progesterone synthesis by $\mathrm{LH}, \mathrm{PGE}_{2}$ and isoproterenol in the bovine CL in vitro. Biol. Reprod. 17, 514-518.

Grob, H.S. (1974) Follicle growth in denervated ovaries of hypophysectomized mice. Fedn Proc. Fedn Am. Socs exp. Biol. 33, 213.

Hanssens, M.C.A.J.A., Selby, C., Filshie, G.M., Gilbert, B.J. \& Symonds, E.K. (1983) Changes in plasma steroid hormones during treatment of preterm labour with ritodrine-HCl. Br. J. Obstet. Gynaecol. 90, $847-853$.

Jordan, A.W. (1980) Ovarian $\beta$-adrenergic receptor concentrations during various reproductive states in the rat. Biol. Reprod. 22, Suppl. 1, 106A, abstr.

Jordan, A.W., Caffrey, J.L. \& Niswender, G.D. (1978) , Catecholamine-induced stimulation of progesterone and adenosine $3^{\prime}, 5^{\prime}$-monophosphate production by dispersed ovine luteal cells. Endocrinology 103, 385-392.

Kannisto, P., Owman, Ch. \& Walles, B. (1985) Involvement of local adrenergic receptors in the process of ovulation in gonadotrophin-primed immature rats. $J$. Reprod. Fert. 75, 357-362.

Kornhauser, D.M., Wood, A.J.J., Vestal, R.E., Wilkinson, G.R., Branch, R.A. \& Shand, D.G. (1978) Biological determinants of propranolol disposition in man. Clin. Pharmacol. Ther. 23, 165-174.

Lambertsen, C.J., Greenbaum, D.F., Wright, K.H. \& Wallach, E.E. (1976) In vitro studies of ovulation in the perfused rabbit ovary. Fert. Steril. 27, 178-187.

Lamond, D.R., Gaddy, R.G. \& Kennedy, S.W. (1972) Influence of season and nutrition on luteal plasma progesterone in rambouillet ewes. J. Anim. Sci. 34, 626-629.

Longley, W.H. (1910) Factors which influence the maturation of the egg and ovulation in the domestic cat. Science, N.Y. 31, 465-466.

McCracken, J.A. (1980) Hormone receptor control of prostaglandin $\mathrm{F}_{2} \alpha$ secretion by the ovine uterus. $A d v$. Prost. Thromb. Res. 8, 1329-1344.

Metcalf, M.G., Skidmore, D.S., Lowry, G.F. \& Mackenzie, J.A. (1983) Incidence of ovulation in the years after the menarche. $J$. Endocr. 97, 213-219.

Neilson, D., Jones, G.S., Woodruff, J.D. \& Goldberg, B. (1970) The innervation of the ovary. Obst. Gynec. Surv. 25, 889-904.

Norjavaara, E., Selstam, G., Damber, J.-E. \& Johansson, B.-M. (1983) In vivo effect of noradrenaline on the cyclic AMP level in rat corpora lutea. Acta physiol. scand. 119, 113-116.

Okulicz, W.C., Evans, R.W. \& Leavitt, W.W. (1981) Progesterone regulation of the occupied form of nuclear estrogen receptor. Science, N.Y. 213, 1503-1505.

Peppler, R.D. \& Jacobs, J.J. (1976) The effect of adrenalectomy on ovulation and follicular development in the rat. Biol. Reprod. 15, 173-178.

Ramaley, J.A. (1981) Stress and fertility. In Environmental Factors in Mammal Reproduction, pp. 127-141. Eds D. Gilmore \& B. Cook. Macmillan, London.

Rao, L.V. \& Pandey, R.S. (1982) Seasonal changes in plasma progesterone concentrations in buffalo cows (Bubalus bubalis). J. Reprod. Fert. 66, 57-61.

Ratner, A., Sanborn, C.R. \& Weiss, G.K. (1980) $\beta$ Adrenergic stimulation of cAMP and progesterone in rat ovarian tissue. Am. J. Physiol. 239, E139-E143.

Richardson, M.C. \& Masson, G.M. (1980) Progesterone production by dispersed cells from human corpus luteum: stimulation by gonadotrophins and prostaglandin $F_{2} \alpha$; lack of response to adrenaline and isoprenaline. $J$. Endocr. 87, 247-254.

Rosenberg, M., Folman, Y., Herz, Z., Flamenbaum, I., Berman, A. \& Kaim, M. (1982) Effect of climatic con- 
ditions on peripheral concentrations of $\mathrm{LH}$, progesterone and oestradiol-17 $\beta$ in high milk-yielding cows. J. Reprod. Fert. 66, 139-146.

Selye, H. (1950) The Physiology and Pathology of Exposure to Stress. Acta Incorporated, Montreal.

Snedecor, G.W. \& Cochran, W.G. (1967) Statistical Methods, 6th edn, pp. 135-139. Iowa State University, Ames.

Sokal, R.R. \& Rohlf, F.J. (1981) Biometry, 2nd edn. W.H. Freeman, San Francisco.

Spink, R.R., Malvin, R.L. \& Cohen, B.J. (1966) Determination of erythrocyte half life and blood volume in cats. Am. J. vet. Res. 27, 1041-1043.

Stott, G.H. \& Wiersma, F. (1973) Climatic thermal stress, a cause of hormonal depression and low fertility in bovine. Int. J. Biometeor. 17, 115-122.

Virutamasen, P., Hickok, R.L. \& Wallach, E.E. (1971) Local ovarian effects of catecholamines on human chorionic gonadotrophin-induced ovulation in the rabbit. Fert. Steril. 22, 235-243.
Weiner, N. (1980) Norepinephrine, epinephrine, and the sympathomimetic amines. In The Pharmacological Basis of Therapeutics, 6th edn, p. 154. Eds A. G. Gilman, L. S. Goodman \& A. Gilman. Macmillan, New York.

Wheeler, A.G. (1978) Comparisons of the ovulatory and steroidogenic activities of the left and right ovaries of the ewe. J. Reprod. Fert. 53, 27-30.

Wheeler, A.G. \& Blackshaw, A.W. (1986) Effect of cold and hot ambient temperatures on plasma progesterone concentrations in ewes with intact and denervated ovaries containing experimentally maintained corpora lutea. J. Reprod. Fert. 78, 353-360.

Whitacre, F.E. \& Barrera, B. (1944) War amenorrhea. $J$. Am. med. Assoc. 124, 399-403.

Zsolnai, B., Varga, B. \& Horvath, E. (1982) Increase of ovarian progesterone secretion by $\boldsymbol{\beta}_{2}$-adrenergic stimulation in oestrous rats. Acta endocr., Copenh. 101, 268-272.

Received 16 May 1986 